\title{
Enhanced immuno-detection of shed extracellular domain of HER-2/neu
}

\author{
Sinang Chourb, Brian C. Mackness, Leslie R. Farris, Melisenda J. McDonald
}

Biochemistry Program, Chemistry Department, University of Massachusetts, Lowell, USA; Melisenda_McDonald@uml.edu.

Received 10 October 2009; revised 20 November 2009; accepted 1 December 2009.

\begin{abstract}
HER-2/neu oncogene is over-expressed and amplified in patients associated with metastatic breast cancer. An increased level $(>15 \mathrm{ng} / \mathrm{mL})$ in the shed extracellular domain (sECD-HER 2/neu) is indicative of the potential presence and associated progression of this disease. A fluorescent ELISA incorporating the newly developed ALYGNSA antibody-orientation system revealed a 10 -fold increase in sensitivity $(\leq 0.63$ $\mathrm{ng} / \mathrm{mL}$ ) of $s E C D-H E R$ 2/neu when compared to a control standard ELISA kit $(\leq 7.5 \mathrm{ng} / \mathrm{mL})$. This enhanced mode of detection has the potential to not only address breast and other cancers per se but also permit an in depth evaluation of "shed extracellular domains", in general, and the role of these "proteolytic derived factors" in physiological signalling at normal levels.
\end{abstract}

Keywords: HER-2/neu; Shed Extracellular Domain; C-erbB2; Breast Cancer Marker; ELISA; Fluorescent immunoassay; ALYGNSA

\section{BACKGROUND}

Breast cancer, which is the most diagnosed form of cancer in women, will account for $27 \%$ of cancer cases in 2009 according to the American Cancer Society. The human epidermal growth factor HER-2 oncogene (cerbB-2) has been implicated in this disease [1-4]. The HER-2/neu oncoprotein is amplified and over-expressed in 25 to 30 percent of patients with aggressive breast cancer. Further, the full-length receptor (p185HER2) undergoes a proteolytic cleavage resulting in the release of the soluble shed ECD/HER2 (sECD-HER 2/neu) fragment. The resultant truncated intracellular form containing the kinase domain is associated with enhanced signaling activity and consequently contributes to metastatic breast cancer [5]. The $s E C D / H E R$ 2/neu fragment from the surface of breast cancer cells once shed into the blood of individuals can be quantified, making a useful breast cancer biomarker.

Measured levels of the $S E C D-H E R$ 2/neu protein greater than $15 \mathrm{ng} / \mathrm{ml}$ were indicative of the potential presence and the associated progression of primary tumors to metastatic breast cancer $[4,6,7]$. Most commercially available assays use this concentration as a focal point leaving smaller amounts undetected. Since the over expression of HER-2/neu oncogene is a useful tool as a prognostic and predictive marker for breast cancer, development of a more sensitive biomarker assay appeared ideal for monitoring the progression, the early recurrence of metastatic breast cancer, and the response to therapy $[5,8,9]$. A more sensitive assay would also allow for the establishment of an individual's baseline level of $s E C D$ $H E R-2 / n e u$ protein through which more accurate detection of unexpected increase might be achieved. Finally, an improved assay may be useful to monitor the normal signaling activity of the Her-2/neu pathway.

A current, rapid method to detect Her-2/neu protein in biological fluids, such as serum, is the Enzyme-Linked Immunosorbant Assay (ELISA) [10,11]. A typical commercial HER-2/neu ELISA assay uses the "sandwich" principle, where a capture antibody is directly adsorbed onto a substrate. The detector antibody is labeled with an enzyme, which upon addition of the substrate, produces a colored product quantifiable by absorbance analysis. In this study, an assay was developed for the detection of the $s E C D-H E R-2 / n e u$ protein utilizing the ALYGNSA system consisting of a protein biolinker (Protein G') and poly (methyl methacrylate) or PMMA, a thermoplastic polymer. The unique interaction of Protein G' with PMMA has been demonstrated to improve human IgG capture antibody alignment/orientation [12] and provide greater sensitivity in detection of cancer biomarkers CA-125 [13] and PSA [14].

In this report, this system has been shown to detect an order of magnitude lower level of (sECD-HER 2/neu) than the commercial ELISA kit counterpart.

\section{MATERIALS AND METHODS}

\subsection{ELISA Assay Method}

Microwells coated with mouse monoclonal anti-HER-2/-/ 


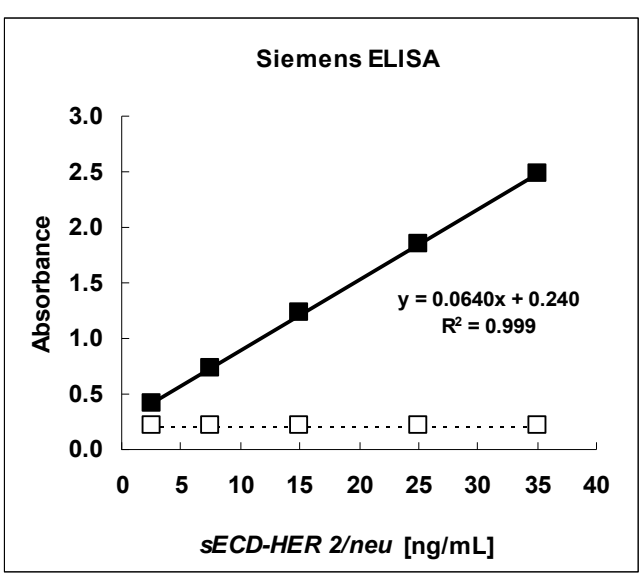

Figure 1. Siemens $s E C D-H E R$ 2/neu ELISA: Results for assay (closed squares) and baseline (open squares) points. The standard deviation values are presented in Table 1. The LOD was determined by the blank value +2 times the standard deviation. The intra-assay variability $(\% \mathrm{CV})$ or [(standard deviation / mean)*100] was calculated based on the difference in duplicate measurements. The highly linear relationship between the standards was confirmed by the coefficient of determination $\left(\mathrm{R}^{2}\right)$ value of 0.998 . Each data point represents the average of eight replicates.

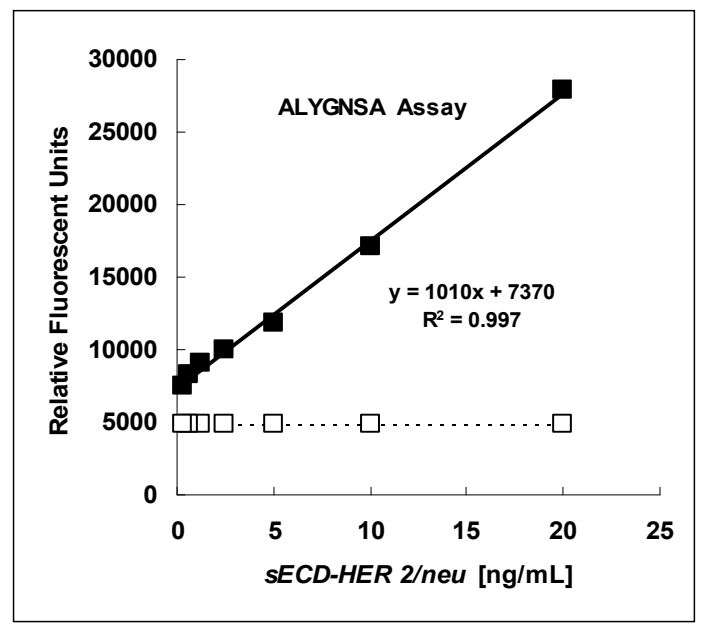

Figure 2. $s E C D-H E R$ 2/neu ALYGNSA: Results for assay (closed squares) and baseline (open squares) points. The standard deviation values are presented in Table 2. As with the Her-2/neu ELISA, the ALYGNSA method showed a highly linear response as indicated by the $\mathrm{R}^{2}$ value of 0.997 . Each data point represents the average of six replicates.

neu protein antibody, HER-2/neu reference standards, sample diluent, detector antibody, substrate diluent, conjugate diluent, conjugate concentrate, substrate tablet, substrate diluent and stop solution were used in the HER-2/neu colorimetric ELISA (Siemens). The ELISA assay was performed according to manufacturer's in-
Table 1. Siemens ELISA kit detection of $s E C D-H E R$ 2/neu.

\begin{tabular}{cccc}
\hline$[\mathbf{n g} / \mathbf{m L}]$ & Absorbance & $\pm \mathbf{S D}$ & $\mathbf{\% C V}$ \\
\hline 35 & 2.50 & 0.25 & 10 \\
25 & 1.80 & 0.17 & 9.4 \\
15 & 1.20 & 0.10 & 8.3 \\
$7.5^{*}$ & $\mathbf{0 . 7 4 0}$ & $\mathbf{0 . 1 2}$ & $\mathbf{1 6}$ \\
2.5 & 0.410 & 0.24 & 59 \\
0 & 0.220 & 0.18 & 82 \\
\hline
\end{tabular}

* Level of Detection (LOD) was $\leq 7.5 \mathrm{ng} / \mathrm{mL}$ and was defined as the blank +2 standard deviations (SD) [9]. The intra-assay variability $(\% \mathrm{CV})$ or [(standard deviation / mean) x 100] was calculated based on the difference in duplicate measurements.

Table 2. SECD-HER 2/neu detection by ALYGNSA.

\begin{tabular}{cccc}
\hline$[\mathbf{n g} / \mathbf{m L}]$ & Fluorescence & \pm SD & $\mathbf{\% C V}$ \\
\hline 20 & 27900 & 1100 & 3.9 \\
10 & 17100 & 790 & 4.6 \\
5 & 11900 & 2300 & 19 \\
2.5 & 10000 & 1300 & 13 \\
1.25 & 9080 & 105 & 1.2 \\
$\mathbf{0 . 6 3}$ & $\mathbf{8 3 3 0}$ & $\mathbf{5 8}$ & $\mathbf{0 . 7}$ \\
0.31 & 7450 & 190 & 2.5 \\
0 & 4870 & 1400 & 29 \\
\hline
\end{tabular}

* Level of Detection (LOD) was $\leq 0.63 \mathrm{ng} / \mathrm{mL}$ as defined above. The $\% \mathrm{CV}$ was also calculated; value and SD of blank were consistent with previously published reports $[12,13]$.

structions. First, the HER-2/neu antigen reference sample was diluted to $9.21 \mathrm{ng} / \mathrm{mL}$ with sample diluent. The standards and control were dispensed into the appropriate wells at $100 \mu \mathrm{L} /$ well and incubated at $37^{\circ} \mathrm{C}$ for 3 hours. The plate was rinsed three times with $350 \mu \mathrm{L} /$ well volume of plate wash buffer. Then, $100 \mu \mathrm{L}$ of detector antibody was dispensed into each well (except for the substrate blank wells) and incubated at $37^{\circ} \mathrm{C}$ for 1 hour. After washing, $100 \mu \mathrm{L}$ of working conjugate solution was applied to all wells except for the substrate blank wells. Following incubation at room temperature for 30 minutes, $100 \mu \mathrm{L}$ of working substrate solution was applied to all wells, including the substrate blank wells. After incubation at room temperature for 45 minutes in the dark, $100 \mu \mathrm{L} /$ well of stop solution was applied to all the wells and the plate was read for absorbance at 498 $\mathrm{nm}$ on a BioRad plate reader.

\subsection{ALYGNSA Assay}

Protein and antibody reagents used in the $s E C D$ HER-2/neu ALYGNSA assay were recombinant Protein G' (Sigma), C-erbB-2 monoclonal antibody (Labvision, 
clone\# c-erbB-2/HER-2/neu Ab 20) and HER-2/neu antigen, reference sample (Siemens). Poly (methyl methacrylate) (PMMA) (Sigma) was used to coat polypropylene plates (Corning). The coating buffer was phosphate buffered saline (PBS); pH 7.4. A PMMA solution in acetone prepared to a concentration of $10 \mathrm{mg} / \mathrm{mL}$ was solution cast onto polypropylene plates and incubated overnight at room temperature in a desiccator. After drying, the plates were washed with one volume of $1 \%$ SDS in PBS, pH 7.4 and 3 volumes of PBS. The PMMA plates were coated with recombinant Protein G' $(1 \mu \mathrm{g} / \mathrm{mL}$ at 50 $\mu \mathrm{L} /$ well) and incubated overnight at $4^{\circ} \mathrm{C}$. After washing, the plates were blocked with $5 \%$ NFDM at $150 \mu \mathrm{L} /$ well for 2 hours at room temperature, and then re-washed. The plates were coated with the primary HER-2 antibody at $2 \mu \mathrm{g} / \mathrm{mL}$ at $50 \mu \mathrm{L} /$ well and incubated overnight at $4^{\circ} \mathrm{C}$. After washing, the plates were re-blocked and washed. The reference sample (antigen) was diluted to $20 \mathrm{ng} / \mathrm{mL}$ and $100 \mu \mathrm{L}$ applied to the top rows of each plate. A 1:1 serial dilution in PBS was performed and carried out to $0.31 \mathrm{ng} / \mathrm{mL}$. The plates were incubated for 1 hour at room temperature, and then washed. The HER2/neu secondary antibody was labeled using DyLight 488 from Pierce. First, $8 \mu \mathrm{L}$ of the Borate Buffer $(0.67$ M) was added to $100 \mu \mathrm{L}$ of $1 \mathrm{mg} / \mathrm{mL}$ HER-2/neu antibody in PBS. Then, $100 \mu \mathrm{L}$ of the prepared protein was added to the vial of DyLight Reagent, briefly centrifuged and incubated for 60 minutes at room temperature in the dark. One hundred microliters of the purification resin was added into the spin column and centrifuged for 1 minute at $\sim 1,000 \mathrm{x}$ g. In a new tube $100 \mu \mathrm{L}$ of the labeling reaction was added to the spin column, mixed with the purification resin and centrifuged for 1 minute at $\sim 1,000 \mathrm{x}$ g to collect the purified protein. This fluorescent-labeled secondary HER-2 antibody was diluted to 2 $\mu \mathrm{g} / \mathrm{mL}$, and applied at $50 \mu \mathrm{L} /$ well. Following incubation for 1 hour at room temperature and washing, the plates were read for fluorescence on a BioTek Microplate Reader.

\section{RESULTS}

\subsection{ELISA Assay}

An ELISA kit (Siemens) served as a model for a commercially available method to detect $s E C D-H e r-2 / n e u$ protein in breast cancer. A standard curve of absorbance versus concentration of $s E C D-H E R \quad 2 / n e u(\mathrm{ng} / \mathrm{mL})$ was generated after multiple runs of the Siemens ELISA kit (Figure 1). The limit of detection (LOD) for $s E C D$ $H E R-2 /$ neu protein, in our hands, was determined to be $\leq 7.5 \mathrm{ng} / \mathrm{mL}$ (Table 1).

\subsection{ALYGNSA Assay}

The ALYGNSA assay for $s E C D-H E R$ 2/neu detection employs a sandwich assay protocol similar to the ELISA method, except for the protein biolinker, Protein G', and the fluorescently labeled detector antibody; Fluorescence detection analysis is a more sensitive method of analysis than colorimetric detection employed in the ELISA method. Multiple determinations revealed an assay LOD of $\leq 0.63 \mathrm{ng} / \mathrm{mL}$ for $s E C D$-HER 2/neu (Figure 2, Table 2) and, hence, a 10-fold greater sensitivity than the Siemens ELISA kit.

\section{DISCUSSION}

\section{1. sECD-HER 2/neu Detection: Importance in Breast Cancer Treatment}

HER-2/neu is over-expressed and amplified in patients with metastatic breast cancer. An increase serum level $(>15 \mathrm{ng} / \mathrm{mL})$ of its shed extracellular domain $(s E C D$ $H E R 2 /$ neu ) is indicative of the potential presence and associated progression of this disease. In this report a newly developed ALYGNSA system has been shown to detect an order of magnitude lower level of $S E C D$-HER $2 /$ neu than the commercial ELISA kit counterpart. Prevention of HER-2/neu overexpression has been extensively demonstrated using novel HER-2/neu-blocking agents $[8,15,16]$. Monoclonal therapeutic antibodies known to bind to extracellular domains of HER-2/neu have been well characterized [17 and references therein]; they include: pertuzumab/Omnitarg ${ }^{\mathrm{TM}}$ which acts upon Domain II and is believed to hinder receptor dimerization; cetuximab/Erbitux ${ }^{\mathrm{TM}}$ which blocks essential structural transitions of Domain III; and perhaps the most well known and of greatest interest here, trastuzumab/Herceptin ${ }^{\mathrm{TM}}$ which binds to Domain IV blocking the action of sheddase and inhibiting $S E C D-H E R$ 2/neu formation. Trastuzumab was the first FDA approved HER-2/neu monoclonal antibody used in the treatment of HER2/neu overexpression in breast cancer patients. sECD-HER $2 /$ neu $(>15 \mathrm{ng} / \mathrm{mL})$ is currently used to select patients for therapy with trastuzumab.

\subsection{SECD-HER 2/neu Quantitation: Detection and Treatment of Additional Cancers}

Numerous reports have focused on evaluation of serum sECD-HER 2/neu levels in patients not only in breast cancer but also in several other tumor types including but not limited to ovarian [18] prostate [19], and lung cancer [20]. Each condition has a unique set of laboratory, pathological, and clinical factors essential to the detection, treatment, and prognosis. Greater detection, evaluation and standardization of $s E C D-H E R 2 /$ neu levels in serum, as well as other cancer biomarkers, may provide a universal approach to epidermal growth factor receptor (EGFR) related cancers [21,22]. 


\section{3. sECD-HER 2/neu Detection: Assessment of Normal Physiological Processes}

EGFR and the other three homologous members of the EGFR family of receptor tyrosine kinase (also referred to as the ErbB or HER family) are comprised of four members: EGFR, HER2, HER3, and HER4. Under normal physiological conditions, the EGFR family governs vital processes including cell growth, cell differentiation, and cellular migration (processes which are altered in cancerous states). Disruption of signaling from the receptors can result in aggressive diseases including many cancers (epithelial tumors) which could possibly lead to poorer outcomes. A recent review [16] has focused on the structural/functional aspects of ligand-induced ErbB receptor structural transitions and dimerization, and mechanistic modes of activation and inhibition. Further, a key part of the EGFR story involves $s E C D-H E R$ 2/neu [23] and its proteolytic processing via protein ectodomain shedding by the ADAM family of proteins [24]. Post-translational processing of extracellular membrane components is a major mode of regulation [25]. The ALYGNSA assay, with its enhanced sensitivity, may be the vehicle that could drive these investigations.

\section{CONCLUSIONS}

This work utilized a fluorescent ELISA incorporating the newly developed ALYGNSA antibody-orientation system which revealed a 10 -fold increase in sensitivity $(\leq 0.63 \mathrm{ng} / \mathrm{mL})$ of $s E C D-H E R$ 2/neu when compared to a control standard ELISA kit $(\leq 7.5 \mathrm{ng} / \mathrm{mL})$. The ALYGNSA assay could aid in evaluation and detection of $s E C D-H E R 2 /$ neu under normal conditions and may provide additional insight into its role in disease states. This experimental success with analytical (buffer-based) samples should encourage future work with clinical (serum-based) samples.

\section{ACKNOWLEDGMENT}

This work was supported by NSF award \# 0425826 and a University of Massachusetts System-Wide CVIP award (MJM). S.C. participated in the NSF Research Experience for Undergraduates (REU) at UMass Lowell. Special thanks to Lisa-Jo Ann Clarizia and Davin Sok for their helpful discussions and support in the early stages of this work, and to Peter S. Chiev and Adrianna Morris for critical reading of this manuscript.

\section{REFERENCES}

[1] Slamon,D.J., Clark, G.M., Wong, S.G., Levin,W.J., Ullrich, A. and McGuire, W.L. (1987) Human breast cancer: correlation of relapse and survival with amplification of the HER-2/neu oncogene. Science, 235, 177-182.
[2] Ménard, S., Pupa, S.M., Campiglio, M. and Tagliabue, E. (2003) Biologic and therapeutic role of HER2 in cancer. Oncogene, 22, 6570-6578.

[3] Ross, J.S., Fletcher, J.A., Linette, G.P., Stec, J., Clark, E., Ayers, M., et al. (2004) Targeted therapy in breast cancer: The HER-2/neu gene and protein. Mol. Cell. Proteomics, 3, 379-398.

[4] Carney, W.P., Leitzel, K., Ali, S., Neumann, R. and Lipton, A. (2007) A HER-2/neu diagnostics in breast cancer. Breast Cancer Res., 9, 207-217.

[5] Bramwell, V.H.C., Doig, G.S., Tuck, A.B., Wilson, S.M., Tonkin, K.S., Tomiak, A., et al. (2009) Changes over time of extracellular domain of HER2 (ECD/HER2) serum levels have prognostic value in metastatic breast cancer. Breast Cancer Res. Treat., 114, 503-511.

[6] Lipton, A., Ali, S.M., Leitzel, K., Demers, L., Chinchilli, V., Engle, L., et al. (2002) Elevated serum HER-2/neu level predicts decreased response to hormone therapy in metastatic breast cancer. J. Clin. Oncology, 20, 14671472.

[7] Fornier, M.N., Seidman, A.D., Schwartz, M.K. and Ghani, F. (2005) Serum HER2 extracellular domain in metastatic breast cancer patients treated with weekly trastuzumab and paclitaxel: association with HER2 status by immunohistochemistry and fluorescence in situ hybridization and with response rate. Ann. Oncology, 16, 234-239.

[8] Slamon, D.J., Jones, B.L., Shak, S., Fuchs, H., Paton, V., Bajamonde, A., et al. (2001) Use of chemotherapy plus a monoclonal antibody against Her2 for metastatic breast cancer that over expresses Her2. N. Engl. J. Med., 344, 783-792.

[9] Payne, R.C., Allard, J.W., Anderson-Mauser, L., Humphreys, J.D., Tenney, D.Y. and Morris, D.L. (2000) Automated assay for HER-2/neu in serum. Clin. Chem., 46, 175-182.

[10] Meenakshi, A., Kumar, R.S. and Kumar, N.S. (2002) ELISA for quantitation of serum c-erbb-2 oncoprotein in breast cancer patients. J. Immunoassay Immunochem., 23, 293-305.

[11] James, R., Thriveni, K., Ramaswamy, G., Krishnamoorthy, L., Mukherjee, G., Deshmane,P.P.V., et al. (2008) Evaluation of immunohistochemistry and enzyme linked immunosorbent assay for Her-2/Neu expression in breast carcinoma. Indian J. Clin. Biochem., 23, 345-351.

[12] Clarizia, L-J.A., Sok, D., Wei, M., Mead, J., Barry, C. and McDonald, M.J. (2009) Antibody orientation enhanced by selective polymer-protein noncovalent interactions. Anal. Bioanal. Chem., 393, 1531-1538.

[13] Sok, D., Clarizia, L-J.A., Farris, L.R. and McDonald, M.J., (2009) Novel fluoroimmunoassay for ovarian cancer biomarker CA-125. Anal. Bioanal. Chem., 393, 1521-1523.

[14] Mackness, B.C., Chourb, S., Farris, L.R. and McDonald, M.J. Polymer-protein enhanced fluoroimmunoassay for prostate-specific antigen. Anal. Bioanal. Chem., DOI 10.1007/s00216-009-3234-6. 
[15] Cho, H.S., Mason, K., Ramyar, K.X., Stanley, A.M., Gabelli, S.B., Denney, D.W., et al. (2003) Structure of the extracellular region of HER2 alone and in complex with the Herceptin Fab. Nature, 421, 756-760.

[16] Zhang, H., Berezov, A., Wang, Q., Zhang, G., Drebin, J., Murali, R., et al. (2007) Erbb receptors: from oncogenes to targeted cancer therapies. J. Clin. Invest., 117, 20512058.

[17] Ferguson, M.K. (2008) Structure-based view of epidermal growth factor receptor regulation. Annu. Rev. Biophys., 37, 353-73.

[18] de Graeff, P., Crijns, A.P.G., ten Hoor, K.A., Klip, H.G., Hollema, H., Oien, K., et al. (2008) The erbb signalling pathway: protein expression and prognostic value in epithelial ovarian cancer. Br. J. Cancer, 99, 341-349.

[19] Osman, I., Mikhail, M., Shuch, B., Clute, M., Cheli, C.D., Ghani, F., et al. (2005) Serum levels of shed Her2/Neu protein in men with prostate cancer correlate with disease progression. J. Urology, 174, 2174-2177.
[20] Salam, I.A. Gaballa, H.E. and Wahab, N.A. (2009) Serum levels of epidermal growth factor and HER-2Neu in non small-cell lung cancer: prognostic correlation. Med. Oncology, 26,161-166.

[21] Hartwell, L., Mankoff, D., Paulovich, A., Ramsey, S. and Swisher, E. (2006) cancer biomarkers: a systems approach. Nature Biotech, 24, 905-908

[22] Jain, K.K. (2008) Innovations, challenges and future prospects of oncoproteomics. Mol. Oncology, 2, 153-160.

[23] Yuan, C.-X., Lasut, A.L., Wynn, R., Neff, N.T., Hollis, G.F., Ramaker, M.L., et al. (2003) Purification of Her-2 extracellular domain and identification of its cleavage site. Protein Expression Purif, 29, 217-222.

[24] Blobel, C.P. (2005) ADAMs: key components in EGFR signalling and development. Nature Rev. Mol. Cell. Biol., 6, 32-44.

[25] Murphy, G., Murthy, A. and Khokha, R. (2007) Clipping, shedding and RIPping keep immunity on cue. Trends Immunol, 29, 75-82. 